\title{
Retraction Problem
}

National Cancer Institute

\section{Source}

National Cancer Institute. Retraction Problem. NCI Thesaurus. Code C62929.

Problem associated with drawing back the device to an intended location. 